\title{
Giant cell arteritis: a review
}

This article was published in the following Dove Press journal:

Eye and Brain

9 March 2013

Number of times this article has been viewed

\author{
Pravin Patil' \\ Niral Karia ${ }^{2}$ \\ Shaifali Jain ${ }^{3}$ \\ Bhaskar Dasgupta' \\ 'Department of Rheumatology, \\ 2Department of Ophthalmology, \\ ${ }^{3}$ Department of Radiology, Southend \\ University Hospital, Westcliff, Essex, \\ United Kingdom
}

Correspondence: Bhaskar Dasgupta

Southend University Hospital, Prittlewell

Chase, Westcliff-on-sea, Essex, SSO ORY,

United Kingdom

Tel +44 $170222 \quad 1048$

Fax +44 1702385909

Email bhaskar.dasgupta@southend.nhs.uk
Abstract: Giant cell arteritis is the most common vasculitis in Caucasians. Acute visual loss in one or both eyes is by far the most feared and irreversible complication of giant cell arteritis. This article reviews recent guidelines on early recognition of systemic, cranial, and ophthalmic manifestations, and current management and diagnostic strategies and advances in imaging. We share our experience of the fast track pathway and imaging in associated disorders, such as large-vessel vasculitis.

Keywords: giant cell arteritis, diagnosis, treatment, polymyalgia rheumatica

\section{Introduction}

Giant cell arteritis is a vasculitis of large-sized and medium-sized vessels causing critical ischemia. It is linked with polymyalgia rheumatica, which is characterized by abrupt-onset pain and stiffness of the shoulder and pelvic girdle muscles. Both conditions occur in the elderly and are associated with constitutional symptoms and a systemic inflammatory response.

Giant cell arteritis is a medical emergency, with permanent visual loss occurring in about $20 \%$ of patients. ${ }^{1}$ There is a need for urgent recognition and immediate initiation of high-dose oral or parenteral steroids to prevent visual loss and other ischemic complications. Patients with ischemic symptoms, such as diplopia, transient visual loss, or jaw/tongue claudication, are at particularly high risk. Elderly patients with sight loss otherwise face poor outcomes, with increased mortality, loss of independence, severe depression, complications such as hip fractures, and admission to residential homes. There may also be poor outcomes related to high-dose prolonged glucocorticoid-related adverse events, such as diabetes, fractures, and cardiovascular complications. Glucocorticoids remain the mainstay of therapy, but disease-modifying conventional agents, such as methotrexate and leflunomide, as well as biological therapy, eg, tocilizumab, an interleukin-6 blocker, have an increasing role in relapsing disease.

This article updates on giant cell arteritis and the related conditions of polymyalgia rheumatica and large-vessel vasculitis; reviews recent guidelines on early recognition of systemic, cranial, and ophthalmic manifestations; current management and diagnostic strategies and advances in imaging, including temporal artery ultrasound, fluorodeoxyglucosepositron emission tomography (FDG-PET), and magnetic resonance imaging (MRI).

\section{Pathology}

Despite recent advances in molecular medicine and immunology, the initial events triggering the cascade of immune and inflammatory reactions responsible for giant 
cell arteritis remain unclear. The initiating step may be the recognition of an infectious agent by activated dendritic cells. The key cell type involved is the CD4+ T cell and the key cytokines are interferon-gamma (implicated in granuloma formation) and interleukin-6, which are key to the systemic response. ${ }^{2}$ The pathogenesis of polymyalgia rheumatica may be similar to that of giant cell arteritis, but in general, polymyalgia rheumatica exhibits less clinical vascular involvement. However, aortic and large vessel involvement is now appreciated in both polymyalgia rheumatica and giant cell arteritis not adequately responding to glucocorticoids.

\section{Epidemiology}

Giant cell arteritis with polymyalgia rheumatica is predominantly seen in the elderly, with cases under the age of 50 years being rare and the incidence increasing with advancing age. . $^{3,4}$ It is more common in females, with a 2.5-3.0-fold relative risk, ${ }^{5}$ and also commoner in Caucasians, particularly in those of Scandinavian descent, but less common in other ethnic groups. The incidence in Olmsted County, MN, is estimated in those over 50 years of age at 18.8 per 100,000 population. ${ }^{6}$ Polymyalgia rheumatica is 2-3 times more common than giant cell arteritis. The incidence is lower in Southern European countries $(<12 / 1,000,000$ in those aged 50 years and older). ${ }^{7}$ A study in the UK showed that the age-adjusted incidence rate of giant cell arteritis was 2.2 per 10,000 person years. ${ }^{8}$ There is some geographic and racial variation. Among Asian populations, giant cell arteritis is infrequent, with Takayasu's arteritis being the more frequently seen large-vessel vasculitis.

\section{Ophthalmic manifestations of giant cell arteritis \\ Visual loss}

Acute visual loss in one or both eyes is by far the most feared and irreversible complication of giant cell arteritis. The main blood supply compromised by giant cell arteritis is to the anterior optic nerve head via the short posterior ciliary arteries and that of the retina via the central retinal artery. There is also choroidal ischemia in giant cell arteritis because short posterior ciliary arteries also supply this region (Figure 1).

In a Swiss study of 85 patients with giant cell arteritis (including 78\% biopsy-positive cases) the authors reported that $62(73 \%)$ presented with ischemic events which included jaw claudication, blurred vision, amaurosis fugax, permanent vision loss, and ischemic stroke. In this study, 29 of 85 patients $(34 \%)$ had permanent vision loss or stroke. ${ }^{9}$

A retrospective Spanish study of 161 patients with biopsy-proven giant cell arteritis found that 42 patients $(26 \%)$ had visual manifestations of their disease, and of these patients, 24 (14.9\%) developed permanent visual loss (9.9\% unilateral, $5 \%$ bilateral). ${ }^{10}$ Moreover, $7.5 \%$ of the patients experienced amaurosis fugax and 5.6\% had diplopia before developing permanent loss of vision. Permanent visual loss was caused by anterior ischemic

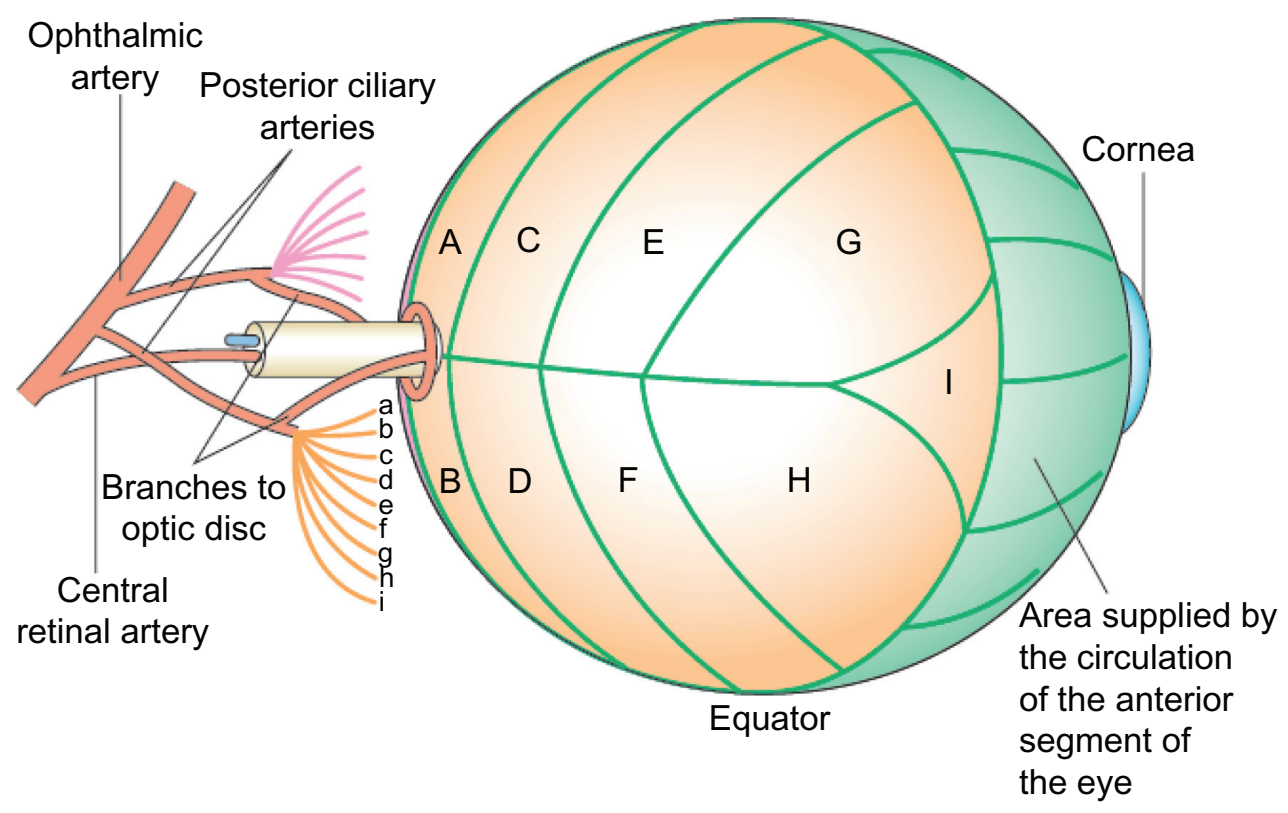

Figure I Schematic representation of posterior retinal circulation. Parts of the blood supply to the optic disk, and the segmentation of the choroidal circulation are illustrated. The short posterior ciliary arteries (a-i) supply segments of the choroid $(\mathbf{A}-\mathbf{I})$ posterior to the equator of the globe.

(C2006 Nature Publishing Group. Reproduced with permission from Aristodemou P, Stanford M. Therapy insight: the recognition and treatment of retinal manifestations of systemic vasculitis. Nat Clin Pract Rheumatol. 2006;2(8):443-451. ${ }^{23}$ 
optic neuropathy in $91.7 \%$ and central retinal artery occlusion in $8.3 \%$, and one patient had a vertebrobasilar stroke causing cortical visual loss.

An Italian study reported visual symptoms in $30.1 \%$ of their subjects, with partial or total visual loss in $19.1 \% .{ }^{11}$ Of the 26 cases with visual loss, 92.3\% were due to anterior ischemic optic neuritis and 7.7\% had central retinal artery occlusion. Visual loss was unilateral in $73.1 \%$ and bilateral in $26.9 \%$. Furthermore, 25 of the 26 patients developed visual loss before corticosteroid therapy was started. However, visual manifestations may arise at any point in the natural course of the disease. If untreated, the other eye is likely to become affected within 1-2 weeks. Once established, visual impairment is usually permanent.

In a recent report by Ezeonyegi et al of 65 patients with giant cell arteritis, 23 patients had visual disturbance at presentation (35.3\%). ${ }^{12}$ Visual loss at presentation occurred in 16 patients $(24.6 \%)$. Over 5 years, 19 patients were left with permanent visual impairment, eight of whom had bilateral loss of vision. Five patients had cerebrovascular complications, the majority of these being transient ischemic attacks. One developed bilateral occipital infarcts with cortical blindness, and another developed oculomotor palsy. Ten patients (15.4\%) presented with neuro-ophthalmic complications in the absence of headache, seven $(70 \%)$ of whom developed permanent visual impairment. Five (7.7\%) patients had cerebrovascular complications. A significant minority of cases without headaches presented with constitutional, polymyalgic, and ischemic symptoms.

Ophthalmology studies report occult giant cell arteritis where visual loss is the presenting symptom. In a study of 85 patients, $21.2 \%$ of the patients with visual loss and positive temporal artery biopsy for giant cell arteritis were reported not to have associated systemic symptoms. ${ }^{13}$ Patients may present with transient visual loss, which is generally unilateral. ${ }^{13}$ However, this may relate to lack of awareness of non-headache presentations, as described above, and underlines the crucial importance of recognizing constitutional and polymyalgic features to reduce delayed recognition and giant cell arteritis diagnosis only after onset of permanent sight loss.

\section{Predictors of visual loss and delay in recognition: "symptom to steroid time"}

Features predictive of permanent visual loss include history of amaurosis fugax, jaw claudication, and temporal artery abnormalities on physical examination. ${ }^{14}$ Amaurosis fugax is an important visual symptom because it precedes permanent visual loss in $44 \%$ of patients. Delay in recognition may be the most important factor, given that the mean time from symptom onset to diagnosis of giant cell arteritis was 35 days in the study by Ezeonyeji et al, and recognition of ischemic symptoms was slow. ${ }^{12}$ Mackie et al found that socioeconomic deprivation may be associated with ischemic complications, ${ }^{15}$ again suggesting that lack of awareness and delay in recognition may be contributory factors.

\section{Diplopia}

Transient or constant diplopia is a frequent visual symptom related to giant cell arteritis. The reported incidence of diplopia in two large studies is approximately $6 \% .{ }^{10,16}$ Ophthalmoplegia in giant cell arteritis is commonly associated with difficulty in upward gaze. ${ }^{17}$ Partial or complete IIIrd or VIth nerve palsy can be revealed on examination. The exact etiology of ophthalmoplegia in giant cell arteritis is not known. Ischemia to the extraocular muscles, the cranial nerves, or brain stem ocular motor pathways have all been postulated as the mechanism of diplopia in giant cell arteritis. ${ }^{18}$

\section{Unusual ocular manifestations}

Rare ocular manifestations of giant cell arteritis include tonic pupil, ${ }^{19}$ Horner syndrome, ${ }^{20}$ and internuclear ophthalmoplegia. ${ }^{21}$ Visual hallucinations seen in patients with cortical blindness are secondary to occipital infarction. Ocular ischemic syndrome is another uncommon manifestation of giant cell arteritis. It is a result of acute inflammatory thrombosis of multiple ciliary arteries causing ischemia of both the anterior and posterior segment. ${ }^{22}$

\section{Blood supply to optic nerve}

The ophthalmic artery, a direct branch of the internal carotid artery, provides most of the blood supply to the eye. Its branches include the central retinal artery, the short and long posterior ciliary arteries, and the anterior ciliary arteries. It is generally agreed that the principal arterial supply to the anterior optic nerve is via the short posterior ciliary arteries. The central retinal artery mainly supplies the retina and superficial anterior optic nerve.

The vascular supply of the optic nerve is complex. The optic nerve head is divided into three regions, as follows:

- The surface nerve fiber layer, which is primarily supplied by arterioles in the adjacent retina. These are branches of the central retinal artery arising in the peripapillary retina.

- The prelaminar and laminar region are mainly supplied by branches from the short posterior ciliary arteries and the Zinn-Haller circle. 
- Tetrolaminar region, supplied by the pial arteries and branches arising from the short posterior ciliary arteries. Venous drainage is via the central retinal vein and pial veins.

\section{Pathophysiology of ocular circulation in giant cell arteritis}

Although giant cell arteritis can cause any lesion affecting the retina to the occipital lobe, the most common cause of vision loss in giant cell arteritis is anterior ischemic optic neuropathy. Arteritic anterior ischemic optic neuropathy in giant cell arteritis is the result of inflammatory occlusion of the short posterior ciliary arteries, which are the main source of blood supply to the optic nerve head. The cause for selective involvement of posterior ciliary arteries is not known. Posterior ciliary artery involvement in giant cell arteritis has been demonstrated on fluorescein fundus angiography and histopathological studies. ${ }^{24}$

In his large series of giant cell arteritis patients, Hayreh has observed that visual loss is often discovered on waking up from sleep in the morning. The fall in blood pressure during sleep may act as the final insult to produce ischemia of the optic nerve head. ${ }^{25}$

Less common causes of vision loss include central retinal artery occlusion, cilioretinal artery occlusion, choroidal infarction, posterior ischemic optic neuropathy, and cortical visual loss due to occipital infarction caused by vertebrobasilar stroke. ${ }^{10,18}$

In an elderly person, visual loss can be due to arteritic or nonarteritic anterior ischemic optic neuropathy. Because the management approach is completely different for those two conditions, the following clues help in establishing an accurate and timely diagnosis (Table 1).

\section{Investigations for diagnosing choroidal and optic nerve ischemia} Fluorescein and indocyanine angiography

Both fluorescein and indocyanine green angiographies are used to study the retinal, choroidal, and optic disc circulation. Angiography is very useful in the diagnosis of giant cell arteritis during the early stages of visual loss to determine its cause. Hayreh has reported that, in almost every patient with giant cell arteritis, occlusion of the posterior ciliary artery was identified in patients with vision loss. ${ }^{25}$ Angiography should be performed within the first days after onset of anterior ischemic optic neuropathy because with the passage of time collaterals develop and delays in choroidal filling cannot be appreciated. ${ }^{26}$ In this imaging modality, sodium fluorescein is intravenously administered to the patient and the passage of fluorescein is observed first throughout the choroidal circulation and then in the retinal circulation. Prolonged choroidal filling time is a highly specific

Table I Features of arteritic and nonarteritic anterior ischemic optic neuropathy

\begin{tabular}{|c|c|c|}
\hline Features & Arteritic anterior ischemic optic neuropathy & Nonarteritic anterior ischemic optic neuropathy \\
\hline Incidence & Relatively less common & Most common form of anterior ischemic optic neuropathy \\
\hline Age & $>60$ years & $\begin{array}{l}\text { Can affect a patient at any age, about } 10 \% \text { of patients under } \\
45 \text { years }\end{array}$ \\
\hline Gender & Three times more common in females & Males and females are affected equally \\
\hline Race & More common in whites & No racial difference \\
\hline Vision loss & Rapid & Gradual \\
\hline Preceding symptoms & Amaurosis fugax, diplopia, jaw/tongue claudication & Amaurosis fugax is extremely rare \\
\hline Systemic symptoms & $\begin{array}{l}\text { Anorexia, weight loss, headache, neck pain, myalgia, } \\
\text { malaise and anemia }\end{array}$ & $\begin{array}{l}\text { Patients with nonarteritic anterior ischemic optic neuropathy } \\
\text { have no systemic symptoms }\end{array}$ \\
\hline Visual field defect & Visual defects are much more extensive and severe & $\begin{array}{l}\text { Loss of vision towards the nasal field and less commonly } \\
\text { altitudinal loss }\end{array}$ \\
\hline Severity & Severe visual loss in range of counting fingers or worse & Relatively less severe \\
\hline Recurrence & High risk of second eye involvement in 2 weeks & Relatively low risk \\
\hline Association & Giant cell arteritis/polymyalgia rheumatica & Diabetes mellitus, hypertension \\
\hline Pathogenesis & $\begin{array}{l}\text { Inflammatory occlusion of the short posterior } \\
\text { ciliary arteries }\end{array}$ & $\begin{array}{l}\text { Transient nonperfusion/hypoperfusion of the optic nerve } \\
\text { circulation below the critical autoregulatory level, causing optic } \\
\text { disc ischemia without choroidal ischemia }\end{array}$ \\
\hline Inflammatory markers & Raised & Normal \\
\hline Fundoscopy & $\begin{array}{l}\text { Chalky white disc swelling } \pm \text { central retinal artery } \\
\text { occlusion or cotton wool spots }\end{array}$ & Diffuse or segmental disc edema \\
\hline Temporal artery biopsy & Vasculitic changes & Not involved \\
\hline Treatment & Blindness preventable with steroids & No proven therapy available \\
\hline Prognosis & Variable & Better outcome \\
\hline
\end{tabular}


angiographic finding. A prolonged retinal artery and venous transit time is a very sensitive sign, but it can also be seen in association with central retinal artery occlusion or central retinal vein occlusion. ${ }^{22}$ Extensive choroidal hypoperfusion and multiple filling defects on angiography are highly suggestive of arteritic anterior ischemic optic neuropathy.

Indocyanine green angiography allows better evaluation of the choroidal circulation. The view of the choroid is normally obscured during fluorescein angiography. Indocyanine green provides greater transmission through the retinal pigment epithelium than the visible wavelengths used in fluorescein angiography. ${ }^{27} \mathrm{~A}$ part from choroidal ischemia, it also demonstrates staining of vessels, which may relate to inflammatory infiltration of the vessel wall. ${ }^{28}$

\section{Ocular Doppler ultrasound}

The color Doppler hemodynamics of giant cell arteritis has been studied in patients with a biopsy-proven diagnosis. ${ }^{29}$ In a color Doppler ultrasound study, Ghanchi et al assessed the effects of giant cell arteritis on orbital blood flow. Absence of detectable blood flow in the posterior ciliary arteries was observed in six of seven patients. ${ }^{30}$ Being noninvasive, color Doppler ultrasound allows monitoring of orbital blood flow which correlates with the clinical features of giant cell arteritis. ${ }^{31,32}$ Contrast-enhanced ultrasound has been shown to improve detection of orbital vessels that were otherwise insufficiently detectable. ${ }^{33}$ A hyperechoic embolic occlusion of the central retinal artery in the area of the optic nerve head, referred as the retrobulbar "spot sign", has recently been proposed to exclude giant cell arteritis. ${ }^{34}$ The presence of the "spot sign" is suggestive of embolism, whereas vasculitic hypoperfusion is represented by absent or low-flow only.

\section{Ocular pneumoplethysmography}

Ocular pneumoplethysmography is a noninvasive method for detection of carotid occlusive disease. This technique has been used in the diagnosis of giant cell arteritis. ${ }^{35}$ It measures changes in the volume of the orbits resulting from changes in blood flow, thus indirectly recording ophthalmic artery pressure. ${ }^{22}$ Pneumoplethysmography has been replaced by newer carotid artery imaging methods in the assessment of carotid artery disease.

\section{Outcomes and costs related to sight loss}

There are several reports of economic impact and the cost of visual impairment. ${ }^{36,37}$ Sight loss is particularly dangerous and disabling above the age of 65 years $^{37}$ due to falls, broken hips, other fractures, admission to nursing homes, loss of confidence, and depression. In a series from Southend Hospital (manuscript in preparation) of 11 patients with sight loss, three were deceased within 12 months, and all patients experienced severe depression related to loss of independence and mobility.

In reply to a parliamentary question on sight loss in giant cell arteritis, the Health Minister from the UK Department of Health (Hansard 1412, 2012) ${ }^{38}$ replied that up to 3000 persons with giant cell arteritis in the UK may face visual loss every year (estimated from a giant cell arteritis incidence of 2.2/1000 patient years by Smeeth et $\mathrm{al}^{8}$ and $25 \%$ incidence of sight loss at presentation). The Minister of Health admitted that this constitutes a large burden of disease and many cases could be prevented by earlier recognition and treatment.

Monocular or occasional binocular vision loss, particularly in the elderly, has major consequences for quality of life. ${ }^{39}$ Patients with monocular vision loss are willing to trade one-in-three of their remaining lifetime for unimpaired vision. The trade-off rises to two-in-three for patients with binocular vision loss. According to the Royal National Institute of Blind People economics study, sight loss in the adult UK population imposes a large economic burden, totaling $£ 6.5$ billion in 2008. In addition, loss of healthy life and loss of life due to premature death associated with sight loss also impose a large cost on society. It is predicted that by 2020 , the number of people with sight loss from all causes will rise to over 2,250,000 in the UK, and by 2050, this number will double to nearly four million. ${ }^{40}$

\section{Management and diagnostic strategies for giant cell arteritis Constitutional symptoms}

Most patients with giant cell arteritis have features of a systemic inflammatory response, with 50\% patients developing systemic symptoms such as fever, weight loss, and raised inflammatory markers ${ }^{41,42}$ Large-vessel disease in giant cell arteritis may present without overt ischemic manifestations in a number of ways, including fever of unknown origin, unexplained anemia, a constitutional syndrome characterized by asthenia, anorexia, and weight loss, or isolated polymyalgia rheumatica refractory to steroids. ${ }^{43}$

\section{Cranial symptoms}

Headache is the main symptom in more than $60 \%$ of patients. ${ }^{44}$ This is usually a sudden-onset, severe, localized pain in the temporal region, but it may affect the occipital region and is sometimes poorly localized. Clinical findings 
include a tender, beaded, thickened and pulseless temporal artery. The scalp is also usually tender.

\section{Large artery involvement}

Large artery involvement with aortitis and upper limb arterial involvement (subclavian, axillary, brachial) can present with constitutional symptoms, upper extremity claudication, absent pulses or bruits in the neck and arms, or Raynaud's phenomenon, and as polymyalgia rheumatica without adequate response to steroids. Aortic disease is generally observed as a late complication in the extended followup of patients with giant cell arteritis. ${ }^{45}$ A report from the Mayo Clinic found that large artery complications occurred in $22 \%-27.3 \%$ of patients with giant cell arteritis, with an incidence of 30.5 per 1000 person-years at risk. ${ }^{45}$ Overall, $18 \%$ of this cohort had aortic aneurysm or dissection, and $13 \%$ had large artery stenosis. Large artery involvement correlated negatively with cranial artery disease (hazard ratio 0.1 ) and with high erythrocyte sedimentation rate (hazard ratio 0.8). Angina pectoris, congestive heart failure, and myocardial infarction secondary to coronary arteritis have been reported. ${ }^{46}$

\section{Relationship between giant cell arteritis and polymyalgia rheumatica}

Giant cell arteritis and polymyalgia rheumatica both affect elderly people, their genetic backgrounds are quite similar, and they are both generally responsive to corticosteroids. Polymyalgia rheumatica is present in approximately $50 \%$ of patients with giant cell arteritis, and approximately $10 \%$ of polymyalgia rheumatica patients develop giant cell arteritis. ${ }^{47}$ Polymyalgia rheumatica usually starts abruptly with pain and stiffness in the shoulder and pelvic girdles and neck. ${ }^{48}$ There may also be systemic features including fever, malaise, and weight loss. Patients can also present with distal features, especially hand arthritis, tenosynovitis, and carpal tunnel syndrome.

\section{Temporal artery biopsy}

Temporal artery biopsy is the gold standard for diagnosis and is desirable in all cases. Other tests used are imaging modalities such as duplex ultrasonography, FDG-PET, PET-computed tomography (CT) and MRI.

A temporal artery biopsy should be performed whenever diagnosis of giant cell arteritis is suspected. However, this should not delay treatment, and a contralateral biopsy is not routinely indicated unless the original is suboptimal. Temporal artery biopsy should be at least $1 \mathrm{~cm}$, and preferably $2 \mathrm{~cm}$, in length, ${ }^{49}$ owing to the possibility of skip lesions. It should be noted that temporal artery biopsy may be negative in up to $45 \%$ of cases due to various factors, including suboptimal biopsy technique, temporal artery examination, skip areas, and the effect of preceding steroid therapy. A negative biopsy (in a setting of otherwise typical features of giant cell arteritis) does not exclude the diagnosis of giant cell arteritis. Temporal artery histology may remain positive 2-4 weeks after start of glucocorticoid therapy.

\section{Imaging Ultrasonography of axillary and temporal arteries}

The "halo" sign in ultrasound is quite specific for temporal arteritis. Schmidt et al originally reported the ultrasound appearance of a hypoechoic halo around affected arteries in 1997 (Figure 2). ${ }^{50}$ Other ultrasonographic features include arterial occlusion and stenosis. A meta-analysis of 23 studies found the "halo" sign to have a pooled sensitivity of $69 \%$ and specificity of $82 \%$ compared with biopsy. ${ }^{51} \mathrm{~A}$ large multicenter prospective comparative study in the UK of ultrasonography versus TAB in early giant cell arteritis (TABUL GCA) is testing the diagnostic accuracy, cost-effectiveness, and patient acceptability of the two procedures and whether duplex ultrasound should become routine clinical practice. Ultrasound of the axillary arteries may also give clues regarding large-vessel disease in giant cell arteritis.

\section{Fluorodeoxyglucose positron emission tomography}

Vasculitis in the large vessels can be imaged with FDG-PET. Unfortunately, the temporal artery is not well visualized in PET owing to high activity in the surrounding brain. Blockmans et al studied 35 patients with early biopsy-positive giant cell arteritis. ${ }^{52}$ At diagnosis, 29 patients (83\%) had FDG uptake in at least one vascular territory. Subclavian involvement was most common (74\%), followed by aortic $(50 \%)$ and iliac/femoral involvement (37\%). With treatment,

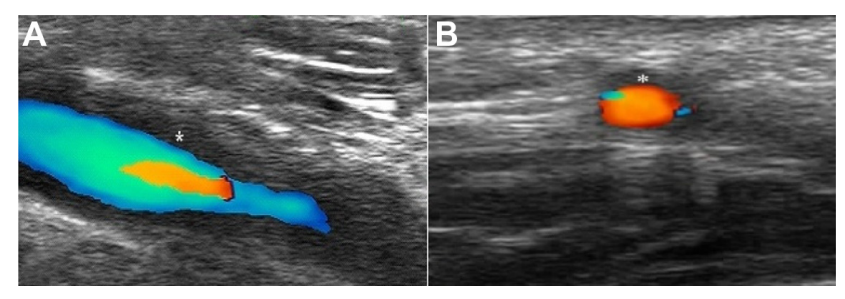

Figure 2 "Halo sign" of giant cell arteritis. Hypoechoic area (asterisk) around the temporal artery in longitudinal view (A) and transverse view (B) in a 70-year-old lady who presented with jaw pain and high inflammatory markers. 
there was a decrease in intensity of FDG uptake by 3 months. However, the authors found no correlation between PET findings and relapse. Another study showed that patients with giant cell arteritis and with increased FDG uptake in the aorta may be more prone to develop dilatation of the thoracic aortic than patients without increased uptake after a mean follow-up of 46.7 months. ${ }^{53}$ This study suggests that FDG-PET scanning has prognostic significance.

FDG-PET-CT combines FDG-PET with CT scanning to show the anatomy of the lesion with superimposed metabolic activity (Figure 3). It addresses the limitations of PET scanning alone (ie, the failure to localize the uptake anatomically and accurately) and may help in differentiating atherosclerosis from vasculitis because calcified plaques may be seen in atherosclerotic lesions. In a retrospective case notes review of 52 rheumatology patients with active polymyalgia rheumatica or giant cell arteritis despite optimal steroid/ methotrexate therapy, 15 had strong FDG uptake in the subclavian, aortic, and axillary arteries, suggesting the presence of large vessel arteritis (manuscript in preparation). All had constitutional symptoms, notably night sweats, weight loss, and lethargy. The average C-reactive protein in patients with large-vessel vasculitis was 112 (range 13-403). There was equal representation of patients with polymyalgia rheumatica and giant cell arteritis. In addition, FDG-PET-CT showed utility in detecting other serious pathology, including cancer in three cases and spondyloarthritis in two cases.
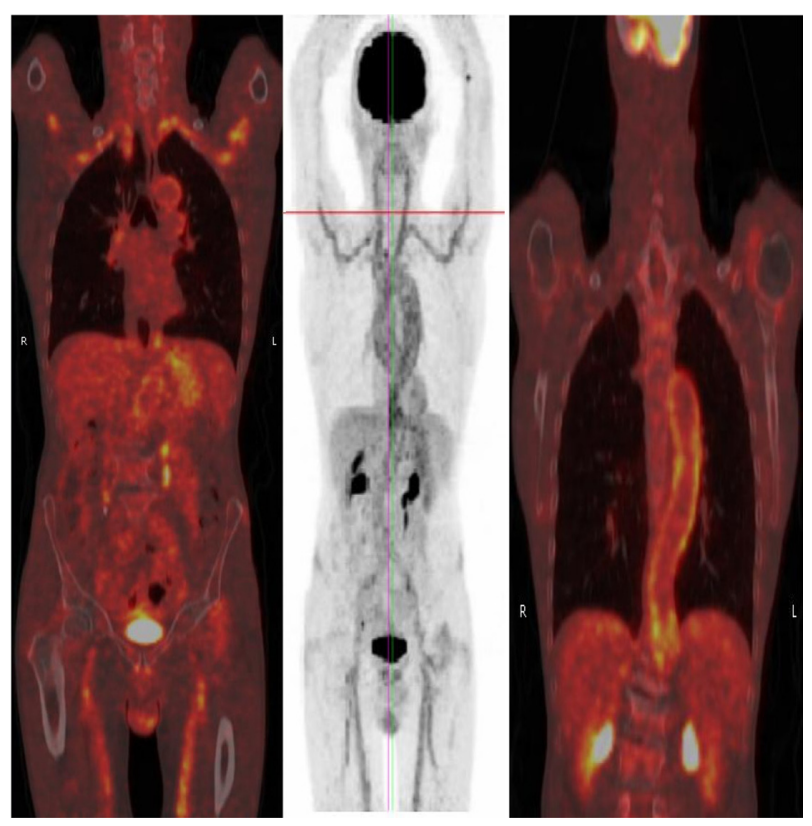

Figure 3 Fluorodeoxyglucose-positron emission tomographic scan showing florid uptake in large vessels including the aorta in a 74-year-old man who presented with polymyalgic symptoms and high inflammatory markers.

\section{Magnetic resonance imaging}

MRI findings include increased vessel wall thickness and edema, increased mural enhancement on post contrast T1-weighted images, and luminal stenosis on magnetic resonance angiography. Bley et al found that MRI of the temporal artery had a sensitivity of $80.6 \%$ and a specificity of $97.0 \%$ for diagnosis of giant cell arteritis by American College of Rheumatology criteria. ${ }^{54}$

\section{Treatment}

\section{Fast track recognition, referral, and treatment of giant cell arteritis}

Analogous to the "Time is Brain" UK ACT-FAST campaign in stroke, "Time is Sight" has been proposed in giant cell arteritis. The key issues in management are urgent recognition and prompt institution of corticosteroid therapy. There is a major delay in instituting treatment for this critically ischemic disease, and a local audit at Southend Hospital in the UK showed that the mean time delay from symptom onset to start of steroids was 35 days. This delay in diagnosis and commencement of steroid therapy may explain the high incidence of irreversible visual complications. ${ }^{55,56}$ A fast track pathway for giant cell arteritis operational at Southend since 2011 has shown a dramatic reduction in irreversible sight loss from $23.3 \%$ to $7.6 \%$ (manuscript in preparation).

A UK Department of Health working group is now evaluating "rollout" of this fast track pathway across the UK. The following are the key areas to address: public awareness, professional awareness, improvement of skills and competence of front-line specialties, such as general practitioners; accident and emergency and acute physicians; treatment to be initiated at the first contact with health professional; easy accessibility of rheumatology consult; a one-stop shop with urgent same-day assessment and relevant investigations by a rheumatologist and/or ophthalmologist (blood tests, ultrasound of temporal arteries, and urgent temporal artery biopsy); and uniform implementation of diagnosis and management guidelines. Reducing unnecessary delays, and standardization of protocols for diagnosing and treating patients with giant cell arteritis may substantially decrease mortality and morbidity associated with sight loss and other ischemic complications. Better patient education should aim towards early identification of new disease, of relapses, minimize presentation delays, and improve adherence to treatment and prevention of steroid-associated adverse events. 


\section{Corticosteroid therapy}

There are no trials comparing different steroid dosing regimens in giant cell arteritis. The recommendations are based on doses suggested in the British Society of Rheumatology guidelines for giant cell arteritis and polymyalgia rheumatica and are mostly based on level 3 evidence. ${ }^{49,57}$

Early high-dose steroid treatment is essential for rapid symptom control and to prevent further visual loss as far as possible..$^{58}$ Improvement in symptoms often begins within hours to days after commencing steroids, with a median time to initial response to an average initial dose of $60 \mathrm{mg} /$ day of 8 days. ${ }^{59}$ However, there was little recovery in fixed visual deficits in the Mayo Clinic study. Initial high-dose intravenous methylprednisolone is often used in clinical practice when patients present with threatened vision. ${ }^{58}$ However, this remains controversial despite findings demonstrating a reduction in cumulative steroid dosage after use of intravenous steroids. ${ }^{60}$

\section{Recommended starting doses of steroids}

British Society of Rheumatology guidelines recommend the following starting doses for steroids:

- Prednisolone 40-60 mg daily for uncomplicated giant cell arteritis (no jaw claudication or visual disturbance)

- Intravenous methylprednisolone 500-1000 mg for 3 days before oral steroids for evolving visual loss (recent onset of visual symptoms over 6-12 hours) or amaurosis fugax (complicated giant cell arteritis)

- Prednisolone $60 \mathrm{mg}$ daily for established visual loss, to protect the contralateral eye

- Treatment along the lines of systemic vasculitis protocols is recommended for large-vessel disease, although this needs to be individualized.

The initial high dose of steroids should be continued for 3-4 weeks and reduced in the absence of any clinical symptoms or any laboratory abnormalities suggestive of ongoing active disease. The steroid tapering should be gradual, provided there is no relapse. In all cases, bone protection should be prescribed according to local guidelines. Proton pump inhibitors should also be considered in most cases, particularly if aspirin is being coprescribed. Most patients are able to discontinue steroids after 1-2 years of treatment. However, the duration of therapy needed is very variable, with some patients experiencing a chronic relapsing course of disease.

\section{Aspirin}

Aspirin has been shown to suppress proinflammatory cytokines in vascular lesions in giant cell arteritis. ${ }^{61}$ There are studies which have shown that antiplatelet or anticoagulant therapy may reduce the risk of ischemic events in patients with giant cell arteritis ${ }^{62,63}$ while other studies have not., ${ }^{9,64}$ Despite this, guidelines recommend the use of aspirin, given that ischemic complications are the biggest source of morbidity in giant cell arteritis.

\section{Treatment of relapsing giant cell arteritis}

Disease relapse in giant cell arteritis can be defined as a rise in erythrocyte sedimentation rate above $40 \mathrm{~mm} / \mathrm{h}$, plus a return of symptoms of giant cell arteritis, ischemic complications, unexplained fever, or symptoms of polymyalgia rheumatica. ${ }^{67}$ It is usually managed by increasing the dose of steroid, depending on type of relapse and number of preceding relapses. Raised inflammatory markers alone do not indicate a relapse in disease, and should not prompt an increase in steroid dose. Management of relapse is as follows:

- Return of headache should be treated with the most recent higher steroid dose

- Jaw claudication requires prednisolone $40-60 \mathrm{mg}$

- Recurrent eye symptoms require the use of either $60 \mathrm{mg}$ of prednisolone or intravenous methylprednisolone

- Symptoms of large-vessel disease (profound constitutional symptoms, high systemic inflammatory response, lack of response to steroids, limb claudication) should prompt further investigation with MRI or PET and use of treatment protocols for systemic vasculitis.

Long-term corticosteroid therapy is associated with a number of adverse effects, which affect up to $86 \%$ of patients. ${ }^{68}$ Therefore, recurrent relapse or failure to wean steroid dosage requires the consideration of steroid-sparing strategies using disease-modifying immunosuppressive drugs. Immunosuppressive agents, such as methotrexate and leflunomide, should be considered at least at the third relapse. Earlier institution of immunosuppressive therapy may be considered, depending on severity and type of relapsing disease.

\section{Oral immunosuppressive agents}

Methotrexate may be used as a steroid-sparing drug. A metaanalysis of studies did suggest a steroid-sparing effect, with a modest effect on cumulative steroid dose. ${ }^{69}$ Alternatively, azathioprine may be used as an adjuvant agent. ${ }^{70}$ Leflunomide has been used for treatment of giant cell arteritis, and it has shown promise in a small number of patients with difficult to treat steroid-resistant disease in our center. ${ }^{71}$ A multicenter randomized controlled trial is in the planning stages. 


\section{Biologic agents}

Anti-tumor necrosis factor-alpha therapy with infliximab has been tried in the management of giant cell arteritis and has not been found to be effective. ${ }^{67}$ Etanercept has not yet been tested in a large trial, although in a small controlled study the results were inconclusive. ${ }^{72} \mathrm{~B}$-cell depletion by rituximab has been used as a steroid-sparing strategy in one patient, with evidence from PET scanning at 4.5 months indicating that the arteritis had resolved..$^{73}$ Another patient with giant cell arteritis and neutropenia was successfully treated with rituximab. ${ }^{74} \mathrm{~A}$ trial of abatacept (a cytotoxic T-lymphocyte antigen [CTLA]-4 fusion protein) in large-vessel vasculitis is currently underway. Recently, treatment with the interleukin-6 inhibitor, tocilizumab, has been shown to be effective in patients with giant cell arteritis. ${ }^{75-77}$ Tocilizumab is indicated in a subgroup of patients with giant cell arteritis and profound constitutional symptoms, a high systemic inflammatory response, and active disease, with involvement of the aorta and its main branches. Larger studies with this therapeutic agent are awaited.

\section{Future directions}

There is an immediate need for implementation of strategies for high-risk case detection and treatment, a fast track pathway, screening for aortic and large vessel disease, and biomarkers for assessment of disease activity, and damage in giant cell arteritis. Better treatments with an improved safety profile compared with steroids and novel clinical trials of cytokine blockade, such as interleukin-6 inhibition with tocilizumab, are required.

\section{Regenerative therapies}

The neuroprotective and regenerative potential of stem cells hold promise in the treatment of eye disorders secondary to optic nerve damage. Transplanted stem cells can secrete neuroprotective factors naturally or with the help of genetic engineering. These neurotrophins increase photoreceptor and retinal ganglion cell survival, and might even facilitate retinal ganglion cell axon regrowth in models of retinal disease, glaucoma, and surgical lesions. ${ }^{78}$ The intravitreal and subretinal routes are the most commonly used transplant strategy. Another strategy is to inject stem cells into the optic nerve and optic tract lesions. Human umbilical cord blood-derived mesenchymal stromal cells injected into an optic tract lesion have been shown to contribute towards neural repair through rescue and regeneration of injured neurons in rats. ${ }^{79} \mathrm{~A}$ study was conducted to assess the effect of autologous intravitreal application of bone marrow-derived mononuclear cells in three human patients with end-stage macular degeneration and glaucoma. ${ }^{80}$ Although this procedure did not result in an improvement of vision, it demonstrated the feasibility of intravitreal injection of autologous bone-marrow-derived cells into the vitreous cavity. We are not aware of trials of such regenerative therapies for optic nerve damage in giant cell arteritis.

\section{Conclusion}

Giant cell arteritis is now recognized as a critically ischemic disease where ischemic complications, large vessel involvement and adverse events from long-term, high-dose steroids may result in poor outcomes, morbidity, and even mortality, significant costs to health care, and a major impact on quality of life. Guidelines on diagnosis and management of giant cell arteritis need implementation to address the wide variation of practice and lack of public and professional awareness of many aspects of this condition. A robust evidence base is lacking, despite the fact that this is the commonest cause of systemic vasculitis. Research programs to address better the understanding of biomarkers, and safer and more effective therapies are urgently needed.

\section{Disclosure}

BD has received honoraria for lectures and served on advisory boards for the National Institute for Health and Clinical Excellence, Roche, Munidpharma, Napp, Merck, and GSK, and has received grant support from the European League Against Rheumatism, American College of Rheumatology, Health Technology Assessment UK, and Research for Patient Benefit UK.

\section{References}

1. Salvarani C, Cantini F, Boiardi L, Hunder GG. Polymyalgia rheumatica and giant cell arteritis. N Engl J Med. 2002;347(4):261-271.

2. Ghosh P, Borg FA, Dasgupta B. Current understanding and management of giant cell arteritis and polymyalgia rheumatica. Expert Rev Clin Immunol. 2010;6(6):913-928.

3. Machado EB, Michet CJ, Ballard DJ, et al. Trends in incidence and clinical presentation of temporal arteritis in Olmsted County, Minnesota, 1950-1985. Arthritis Rheum. 1988;31(6):745-749.

4. Salvarani C, Gabriel SE, O'Fallon WM, Hunder GG. Epidemiology of polymyalgia rheumatica in Olmsted County, Minnesota, 1970-1991. Arthritis Rheum. 1995;38(3):369-373.

5. Gonzalez-Gay MA, Miranda-Filloy JA, Lopez-Diaz MJ, et al. Giant cell arteritis in northwestern Spain: a 25-year epidemiologic study. Medicine. 2007;86(2):61-68.

6. Salvarani C, Crowson CS, O'Fallon WM, Hunder GG, Gabriel SE. Reappraisal of the epidemiology of giant cell arteritis in Olmsted County, Minnesota, over a fifty-year period. Arthritis Rheum. 2004; 51(2):264-268.

7. González-Gay MA, García-Porrúa C, Vázquez-Caruncho M, et al. The spectrum of polymyalgia rheumatica in northwestern Spain: incidence and analysis of variables associated with relapse in a 10 year study. J Rheumatol. 1999;26(6):1326-1332. 
8. Smeeth L, Cook C, Hall AJ. Incidence of diagnosed polymyalgia rheumatica and temporal arteritis in the United Kingdom, 1990-2001. Ann Rheum Dis. 2006;65(8):1093-1098.

9. Berger CT, Wolbers M, Meyer P, Daikeler T, Hess C. High incidence of severe ischaemic complications in patients with giant cell arteritis irrespective of platelet count and size, and platelet inhibition. Rheumatology (Oxford). 2009;48(3):258-261.

10. González-Gay MA, García-Porrúa C, Llorca J, et al. Visual manifestations of giant cell arteritis. Trends and clinical spectrum in 161 patients. Medicine. 2000;79(5):283-292.

11. Salvarani C, Cimino L, Macchioni P, et al. Risk factors for visual loss in an Italian population-based cohort of patients with giant cell arteritis. Arthritis Rheum. 2005;53(2):293-297.

12. Ezeonyeji AN, Borg FA, Dasgupta B. Delays in recognition and management of giant cell arteritis: results from a retrospective audit. Clin Rheumatol. 2011;30(2):259-262.

13. Hayreh SS, Podhajsky PA, Zimmerman B. Occult giant cell arteritis: ocular manifestations. Am J Ophthalmol. 1998;125(4):521-526.

14. Borg FA, Salter VLJ, Dasgupta B. Neuro-ophthalmic complications in giant cell arteritis. Curr Allergy Asthma Rep. 2008;8(4):323-330.

15. Mackie SL, Dasgupta B, Hordon L, et al. Ischaemic manifestations in giant cell arteritis are associated with area level socio-economic deprivation, but not cardiovascular risk factors. Rheumatology (Oxford). 2011;50(11):2014-2022.

16. Hayreh SS, Podhajsky PA, Zimmerman B. Ocular manifestations of giant cell arteritis. Am J Ophthalmol. 1998;125(4):509-520.

17. Reich K, Giansiracusa D, Strongwater S. Neurologic manifestations of giant cell arteritis. Am J Med. 1996;89(1):67-72.

18. Kawasaki A, Purvin V. Giant cell arteritis: an updated review. Acta Ophthalmol. 2009;87(1):13-32.

19. Foroozan R, Buono LM, Savino P, Sergott RC. Tonic pupils from giant cell arteritis. Br J Opthalmol. 2003;87(4):500-519.

20. Shah AV, Paul-Oddoye AB, Madill SA, Jeffrey MN, Tappin ADM. Horner's syndrome associated with giant cell arteritis. Eye (Lond). 2007;21(1):130-131.

21. Ahmad I, Zaman M. Bilateral internuclear ophthalmoplegia: an initial presenting sign of giant cell arteritis. J Am Geriatr Soc. 1999;47(6): 734-736.

22. Mendrinos E, Machinis TG, Pournaras CJ. Ocular ischemic syndrome. Surv Ophthalmol. 2010;55(1):2-34.

23. Aristodemou P, Stanford M. Therapy insight: the recognition and treatment of retinal manifestations of systemic vasculitis. Nat Clin Pract Rheumatol. 2006;2(8):443-451.

24. Hayreh SS, Zimmerman B. Management of giant cell arteritis. Ophthalmologica. 2003;217(4):239-259.

25. Hayreh SS. Giant cell arteritis (temporal arteritis); 2011. Available from: http://webeye.ophth.uiowa.edu/component/content/article/112gca. Accessed August 30, 2012.

26. Valmaggia C, Speiser P, Bischoff P, Niederberger H. Indocyanine green versus fluorescein angiography in the differential diagnosis of arteritic and nonarteritic anterior ischemic optic neuropathy. Retina. 1999;19(2):131-134.

27. Bennett TJ, Barry CJ. Ophthalmic imaging today: an ophthalmic photographer's viewpoint - a review. Clin Experiment Ophthalmol. 2009;37(1):2-13.

28. Sadun F, Pece A, Brancato R. Fluorescein and indocyanine green angiography in arteritic anterior ischaemic optic neuropathy. $\mathrm{Br} J$ Ophthalmol. 1998;82(11):1344-1345.

29. Ho AC, Sergott RC, Regillo CD, et al. Color Doppler hemodynamics of giant cell arteritis. Arch Ophthalmol. 1994;112(7):938-945.

30. Ghanchi F, Williamson TH, Lim CS, et al. Colour Doppler imaging in giant cell (temporal) arteritis: serial examination and comparison with non-arteritic anterior ischaemic optic neuropathy. Eye. 1996;10(Pt 4): 459-464.

31. Tranquart F, Bergès $\mathrm{O}$, Koskas $\mathrm{P}$, et al. Color Doppler imaging of orbital vessels: personal experience and literature review. J Clin Ultrasound. 2003;31(5):258-273.
32. Williamson TH, Baxter G, Paul R, Dutton GN. Colour Doppler ultrasound in the management of a case of cranial arteritis. Br J Ophthalmol. 1992;76(11):690-661

33. Brabrand K, Kerty E, Jakobsen JA. Contrast-enhanced ultrasound Doppler examination of the retrobulbar arteries. Acta Radiol. 2001;42(2):135-139.

34. Ertl M, Altmann M, Torka E, et al. The retrobulbar spot sign in sudden blindness - sufficient to rule out vasculitis? Perspectives in Medicine. 2012:2-7. Available at: http://www.sciencedirect.com/science/article/ pii/S2211968X12000551.

35. Bosley TM, Savino PJ, Sergott RC, et al. Ocular pneumoplethysmography can help in the diagnosis of giant-cell arteritis. Arch Ophthalmol. 1989;107(3):379-381.

36. Meads C. What is the cost of blindness? Br J Ophthalmol. 2003;87(10): 1201-1204.

37. Taylor HR, Pezzullo ML, Keeffe JE. The economic impact and cost of visual impairment in Australia. Br J Ophthalmol. 2006;90(3): 272-275.

38. Anonymous. House of Lords Hansard for July 12, 2012 (Pt 1). Available from: http://www.publications.parliament.uk/pa/ld201213/ldhansrd/ text/120712w0001.htm. Accessed September 13, 2012.

39. Frost A, Eachus J, Sparrow J, et al. Vision-related quality of life impairment in an elderly UK population: associations with age, sex, social class and material deprivation. Eye (Lond). 2001;15(Pt 6):739-744.

40. Anonymous. Key information and statistics - RNIB. Royal National Institute of Blind People. Available from: http://www.rnib.org. uk/aboutus/Research/statistics/Pages/statistics.aspx\#H2Heading2. Accessed September 2, 2012.

41. Salvarani C, Macchioni PL, Tartoni PL, et al. Polymyalgia rheumatica and giant cell arteritis: a 5-year epidemiologic and clinical study in Reggio Emilia, Italy. Clin Experiment Rheumatol. 1987;5(3):205-215.

42. Gonzalez-Gay MA, Garcia-Porrua C, Amor-Dorado JC, Llorca J. Fever in biopsy-proven giant cell arteritis: clinical implications in a defined population. Arthritis Rheum. 2004;51(4):652-655.

43. Gonzalez-Gay MA, Garcia-Porrua C, Amor-Dorado JC, Llorca J. Giant cell arteritis without clinically evident vascular involvement in a defined population. Arthritis Rheum. 2004;51(2):274-277.

44. Gonzalez-Gay MA, Barros S, Lopez-Diaz MJ, et al. Giant cell arteritis: disease patterns of clinical presentation in a series of 240 patients. Medicine. 2005;84(5):269-276.

45. Nuenninghoff DM, Hunder GG, Christianson TJH, McClelland RL, Matteson EL. Incidence and predictors of large-artery complication (aortic aneurysm, aortic dissection, and/or large-artery stenosis) in patients with giant cell arteritis: a population-based study over 50 years. Arthritis Rheum. 2003;48(12):3522-3531.

46. Penn H, Dasgupta B. Giant cell arteritis. Autoimmun Rev. 2003;2(4): 199-203.

47. Franzén P, Sutinen S, von Knorring J. Giant cell arteritis and polymyalgia rheumatica in a region of Finland: an epidemiologic, clinical and pathologic study, 1984-1988. J Rheumatol. 1992;19(2):273-276.

48. Chuang TY, Hunder GG, Ilstrup DM, Kurland LT. Polymyalgia rheumatica: a 10-year epidemiologic and clinical study. Ann Intern Med. 1982;97(5):672-680.

49. Dasgupta B, Borg FA, Hassan N, et al. BSR and BHPR guidelines for the management of giant cell arteritis. Rheumatology. 2010;49(1):1594-1597.

50. Schmidt WA, Kraft HE, Vorpahl K, Völker L, Gromnica-Ihle EJ. Color duplex ultrasonography in the diagnosis of temporal arteritis. $N$ Engl J Med. 1997;337(19):1336-1342.

51. Karassa FB, Matsagas MI, Schmidt WA, Ioannidis JPA. Meta-analysis: test performance of ultrasonography for giant-cell arteritis. Ann Intern Med. 2005;142(5):359-369.

52. Blockmans D, de Ceuninck L, Vanderschueren S, et al. Repetitive 18Ffluorodeoxyglucose positron emission tomography in giant cell arteritis: a prospective study of 35 patients. Arthritis Rheum. 2006;55(1):131-137.

53. Blockmans D, Coudyzer W, Vanderschueren S, et al. Relationship between fluorodeoxyglucose uptake in the large vessels and late aortic diameter in giant cell arteritis. Rheumatology (Oxford). 2008;47(8):1179-1184. 
54. Bley TA, Uhl M, Carew J, et al. Diagnostic value of high-resolution MR imaging in giant cell arteritis. AJNR Am J Neuroradiol. 2007;28(9): 1722-1727.

55. Loddenkemper T, Sharma P, Katzan I, Plant GT. Risk factors for early visual deterioration in temporal arteritis. J Neurol Neurosurg Psychiatry. 2007;78(11):1255-1259.

56. Tarkkanen A. Giant cell arteritis and the ophthalmologist. Acta Ophthalmol Scand. 2002;80(4):353-354.

57. Dasgupta B, Borg FA, Hassan N, et al. BSR and BHPR guidelines for the management of polymyalgia rheumatica. Rheumatology (Oxford). 2010;49(1):186-190.

58. Hayreh SS, Zimmerman B. Visual deterioration in giant cell arteritis patients while on high doses of corticosteroid therapy. Ophthalmology. 2003;110(6):1204-1215.

59. Proven A, Gabriel SE, Orces C, O’Fallon WM, Hunder GG. Glucocorticoid therapy in giant cell arteritis: duration and adverse outcomes. Arthritis Rheum. 2003;49(5):703-708.

60. Mazlumzadeh M, Hunder GG, Easley KA, et al. Treatment of giant cell arteritis using induction therapy with high-dose glucocorticoids: a double-blind, placebo-controlled, randomized prospective clinical trial. Arthritis Rheum. 2006;54(10):3310-3318.

61. Weyand CM, Kaiser M, Yang H, Younge B, Goronzy JJ. Therapeutic effects of acetylsalicylic acid in giant cell arteritis. Arthritis Rheum. 2002;46(2):457-466.

62. Nesher G, Berkun Y, Mates M, et al. Low-dose aspirin and prevention of cranial ischemic complications in giant cell arteritis. Arthritis Rheum. 2004;50(4):1332-1337.

63. Lee MS, Smith SD, Galor A, Hoffman GS. Antiplatelet and anticoagulant therapy in patients with giant cell arteritis. Arthritis Rheum. 2006 54(10):3306-3309.

64. Narváez J, Bernad B, Gómez-Vaquero C, et al. Impact of antiplatelet therapy in the development of severe ischemic complications and in the outcome of patients with giant cell arteritis. Clin Experiment Rheumatol. 2008;26(3 Suppl 49):S57-S62.

65. Gonzalez-Gay MA, Piñeiro A, Gomez-Gigirey A, et al. Influence of traditional risk factors of atherosclerosis in the development of severe ischemic complications in giant cell arteritis. Medicine. 2004;83(6):342-347.

66. Steichen O. Comment on: Risk factors for severe cranial ischaemic events in an Italian population-based cohort of patients with giant cell arteritis. Rheumatology (Oxford). 2009;48(9):1180.

67. Hoffman GS, Cid MC, Rendt-Zagar KE, et al. Infliximab for maintenance of glucocorticosteroid-induced remission of giant cell arteritis: a randomized trial. Ann Intern Med. 2007;146(9):621-630.
68. Hunder GG, Bloch DA, Michel BA, et al. The American College of Rheumatology 1990 criteria for the classification of giant cell arteritis. Arthritis Rheum. 1990;33(8):1122-1128.

69. Mahr AD, Jover JA, Spiera RF, et al. Adjunctive methotrexate for treatment of giant cell arteritis: an individual patient data meta-analysis Arthritis Rheum. 2007;56(8):2789-2797.

70. De Silva M, Hazleman BL. Azathioprine in giant cell arteritis/ polymyalgia rheumatica: a double-blind study. Ann Rheum Dis. 1986;45(2): 136-138.

71. Adizie T, Christidis D, Dharmapaliah C, Borg F, Dasgupta B. Efficacy and tolerability of leflunomide in difficult-to-treat polymyalgia rheumatica and giant cell arteritis: a case series. Int J Clin Pract. 2012; 66(9):906-909.

72. Martínez-Taboada VM, Rodríguez-Valverde V, Carreño L, et al. A double-blind placebo controlled trial of etanercept in patients with giant cell arteritis and corticosteroid side effects. Ann Rheum Dis. 2008;67(5):625-630.

73. Bhatia A, Ell PJ, Edwards JCW. Anti-CD20 monoclonal antibody (rituximab) as an adjunct in the treatment of giant cell arteritis. Ann Rheum Dis. 2005;64(7):1099-1100.

74. Mayrbaeurl B, Hinterreiter M, Burgstaller S, Windpessl M, Thaler J. The first case of a patient with neutropenia and giant-cell arteritis treated with rituximab. Clin Rheumatol. 2007;26(9):1597-1598.

75. Christidis D, Jain S, Das Gupta B. Successful use of tocilizumab in polymyalgic onset biopsy positive GCA with large vessel involvement BMJ Case Rep. 2011;2011. pii: bcr0420114135.

76. Beyer C, Axmann R, Sahinbegovic E, et al. Anti-interleukin 6 receptor therapy as rescue treatment for giant cell arteritis. Ann Rheum Dis. 2011;70(10):1874-1875.

77. Sciascia S, Rossi D, Roccatello D. Interleukin 6 blockade as steroidsparing treatment for 2 patients with giant cell arteritis. J Rheumatol. 2011;38(9):2080-2081.

78. Dahlmann-Noor A, Vijay S, Jayaram H, Limb A, Khaw PT. Current approaches and future prospects for stem cell rescue and regeneration of the retina and optic nerve. Can J Ophthalmol. 2010;45(4):333-341.

79. Zwart I, Hill AJ, Al-Allaf F, et al. Umbilical cord blood mesenchymal stromal cells are neuroprotective and promote regeneration in a rat optic tract model. Exp Neurol. 2009;216(2):439-448.

80. Jonas JB, Witzens-Harig M, Arseniev L, Ho AD. Intravitreal autologous bone-marrow-derived mononuclear cell transplantation. Acta Ophthalmol. 2010;88(4):e131-e132.
Eye and Brain

\section{Publish your work in this journal}

Eye and Brain is an international, peer-reviewed, open access journal focusing on clinical and experimental research in the field of neuro-ophthalmology. All aspects of patient care are addressed within the journal as well as basic research. Papers covering original research, basic science, clinical and epidemiological studies, reviews and

\section{Dovepress}

evaluations, guidelines, expert opinion and commentary, case reports and extended reports are welcome. The manuscript management system is completely online and includes a very quick and fair peer-review system, which is all easy to use. Visit http://www.dovepress.com/ testimonials.php to read real quotes from published authors. 